\title{
Correction to: Oncofertility case report: live birth 10 years after oocyte in vitro maturation and zygote cryopreservation
}

\author{
P. Rodrigues ${ }^{1,2}$ (1) M. Marques ${ }^{1}$ (D) $\cdot$ S. Pimentel ${ }^{1} \cdot$ M. Rato $^{1,2}$ (D) P. Carvalho ${ }^{1} \cdot$ S. C. Correia ${ }^{1} \cdot$ N. Mendes ${ }^{1} \cdot$ H. Amaral $^{3} \cdot$ \\ J. P. Fernandes ${ }^{3} \cdot$ M. J. Carvalho ${ }^{1} \cdot$ C. E. Plancha ${ }^{1,4}(\mathbb{D}$
}

Published online: 5 January 2021

(C) The Author(s) 2021

\section{Correction to: Journal of Assisted Reproduction and Genetics (2020) 37:3089-3094.} https://doi.org/10.1007/s10815-020-01984-3

The article Oncofertility case report: live birth 10 years after oocyte in vitro maturation and zygote cryopreservation, written by P. Rodrigues, M. Marques, S. Pimentel, M. Rato, P. Carvalho, S. C. Correia, N. Mendes, H. Amaral, J. P. Fernandes, M. J. Carvalho and C. E. Plancha, was originally published Online First without Open Access. After publication in volume 37, issue 12, page 3089-3094 the author decided to opt for Open Choice and to make the article an Open Access publication. Therefore, the copyright of the article has been changed to (C) The Author(s) 2020 and the article is forthwith distributed under the terms of the Creative Commons Attribution.

The original article has been corrected.

Publisher's note Springer Nature remains neutral with regard to jurisdictional claims in published maps and institutional affiliations.

The online version of the original article can be found at https://doi.org/ 10.1007/s10815-020-01984-3

\footnotetext{
C. E. Plancha

carlos.plancha@cemeare.pt; cplancha@fm.ul.pt

1 Centro Médico de Assistência à Reprodução - CEMEARE, Lisbon, Portugal

2 Escola de Psicologia e Ciências da Vida, Universidade Lusófona de Humanidade e Tecnologia de Lisboa, Lisbon, Portugal

3 Hospital CUF Descobertas Lisboa, Lisbon, Portugal

4 Inst. Histologia e Biol. Desenvolvimento, Faculdade de Medicina, Universidade de Lisboa, Lisbon, Portugal
} 